\title{
ॠUSGS
}

science for a changing world

Bathymetry and Acoustic Backscatter-Outer Mainland Shelf and Slope, Gulf of Santa Catalina, Southern California

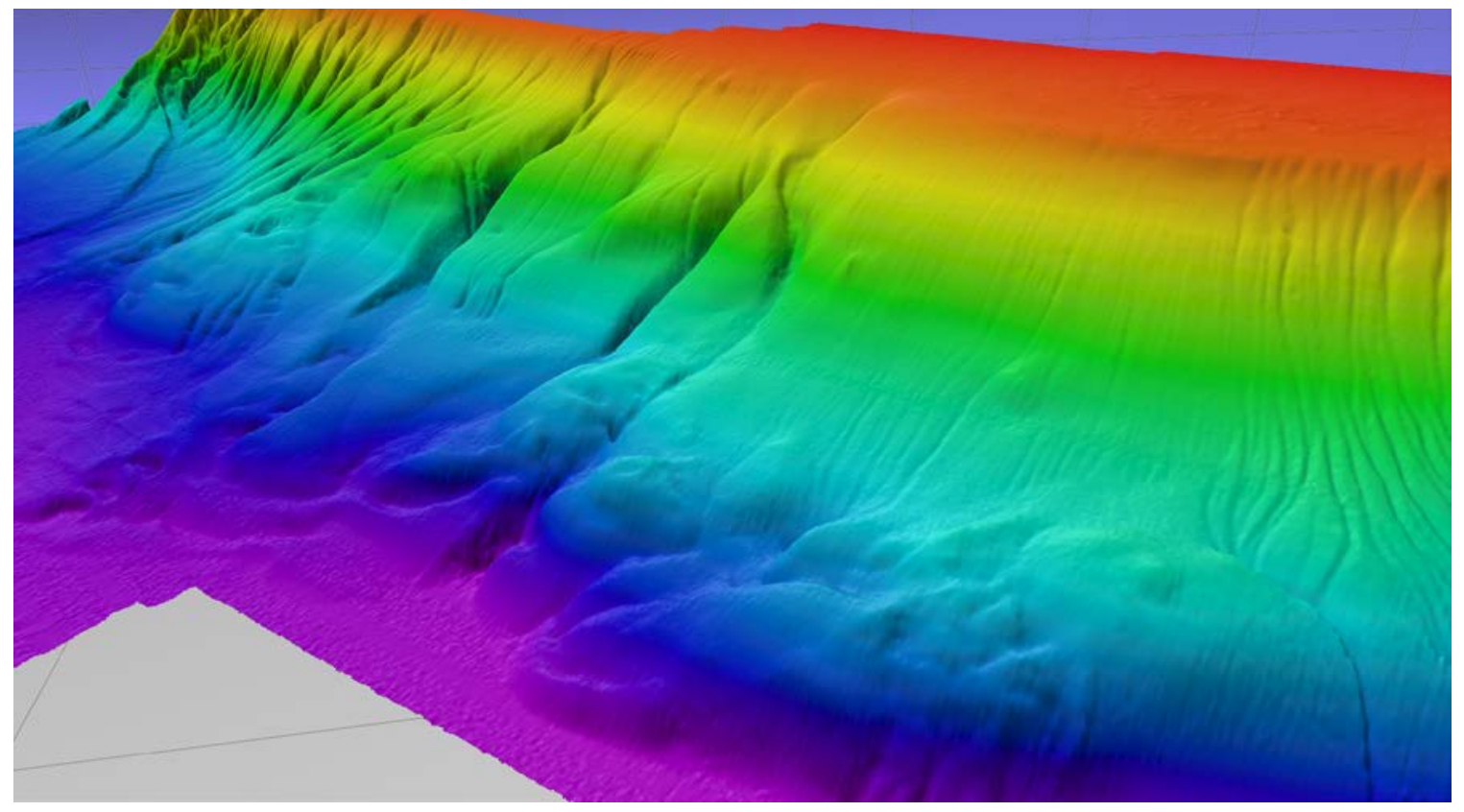

Open File Report 2014-1094

U.S. Department of the Interior

U.S. Geological Survey 
COVER: Perspective view of colored shaded-relief bathymetry, looking northeast, showing lumpy, bulge-like morphology of lower and mid-slope caused by folds and faulting of the San Mateo fold and thrust belt. Area is colored to show depth: red (shallower) to purple (deeper). Vertical exaggeration of perspective view, $5 \mathrm{x}$; distance across bottom, $\sim 7 \mathrm{~km}$. Figure by Peter Dartnell. 


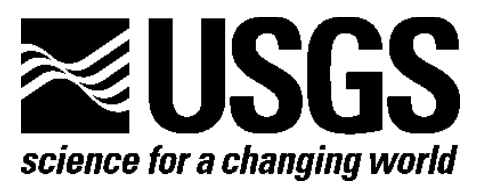

\section{Bathymetry and Acoustic Backscatter-Outer Mainland Shelf and Slope, Gulf of Santa Catalina, Southern California}

By Peter Dartnell, James E. Conrad, Holly F. Ryan, and David P. Finlayson

Open File Report 2014-1094 


\section{U.S. Department of the Interior \\ SALLY JEWELL, Secretary}

\section{U.S. Geological Survey \\ Suzette M. Kimball, Acting Director}

U.S. Geological Survey, Reston, Virginia: 2014

For more information on the USGS-the Federal source for science about the Earth, its natural and living resources, natural hazards, and the environment-visit http://www.usgs.gov or call 1-888-ASK-USGS

For an overview of USGS information products, including maps, imagery, and publications, visit $h$ ttp://www.usgs.gov/pubprod

To order this and other USGS information products, visit http://store.usgs.gov

ISSN 2331-1258 (online)

Suggested citation:

Dartnell, P., Conrad, J.E., Ryan, H.F., Finlayson, D.P, 2014, Bathymetry and acoustic backscatter-outer mainland shelf and slope, Gulf of Santa Catalina, southern California: U.S. Geological Survey Open-File Report 1094, 15 p., http://dx.doi.org/10.3133/ofr20141094.

Any use of trade, firm, or product names is for descriptive purposes only and does not imply endorsement by the U.S. Government.

Although this report is in the public domain, permission must be secured from the individual copyright owners to reproduce any copyrighted material contained within this report. 


\section{Contents}

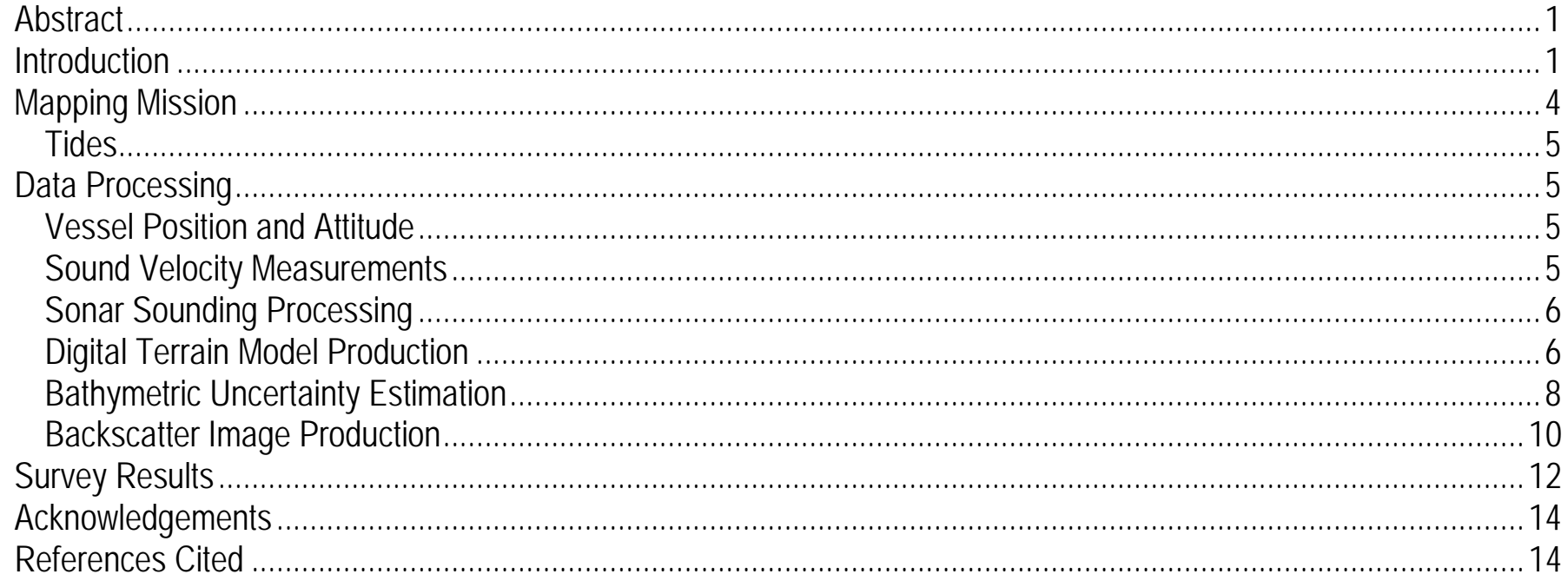

\section{Figures}

Figure 1. Location map of 2010 and 2011 USGS multibeam echosounder surveys in the Gulf of Santa Catalina, southern California........................................................................................................... 2

Figure 2. Map of southern California borderland region showing main fault traces and outline of 2010-2011 USGS multibeam surveys .................................................................................................

Figure 3. Photograph of U.S. Geological Survey Research Vessel Parke Snavely ............................................. 4

Figure 4. Plan view of shaded-relief bathymetry, offshore southern California ................................................ 7

Figure 5. Map showing sub-area of bathymetric standard deviation grid for USGS surveys S-11-10-SC and S-23-10-SC

Figure 6. Plot of randomly selected standard deviation values versus water depth for USGS survey S-07-11-SC.

Figure 7. Map showing acoustic-backscatter imagery of offshore southern California from 2010 and 2011 USGS multibeam-echosounder surveys.

Figure 8. Perspective view of colored shaded-relief bathymetry, looking northwest, showing an uplifted ridge on upper slope adjacent to Rose Canyon Fault Zone.

Figure 9. Perspective view of colored shaded-relief bathymetry, looking northeast, showing a set of northeasttrending fault scarps near base of slope

Figure 10. Perspective view of colored shaded-relief bathymetry, looking northeast, showing lumpy, bulge-like morphology of lower and mid-slope caused by folds and faulting of the San Mateo fold and thrust belt... 14

\section{Tables}

Table 1. Reson 7111 multibeam echosounder sonar specifications.

Table 2. Standard deviation statistics for three USGS surveys that comprised the Gulf of Santa Catalina mapping. 


\section{Conversion Factors}

Inch/Pound to SI

\begin{tabular}{lcl}
\hline & \multicolumn{1}{c}{ Multiply } & \multicolumn{1}{c}{ To obtain } \\
\hline inch (in) & Length & \\
inch (in) & 2.54 & centimeter (cm) \\
foot (ft) & 25.4 & millimeter (mm) \\
mile (mi) & 0.3048 & meter (m) \\
mile, nautical (nmi) & 1.609 & kilometer $(\mathrm{km})$ \\
yard (yd) & 1.852 & kilometer $(\mathrm{km})$ \\
\hline & 0.9144 & meter (m) \\
\hline acre & Area & \\
acre & 4,047 & square meter $\left(\mathrm{m}^{2}\right)$ \\
acre & 0.4047 & hectare (ha) \\
acre & 0.4047 & square hectometer $\left(\mathrm{hm}^{2}\right)$ \\
square foot $\left(\mathrm{ft}^{2}\right)$ & 0.004047 & square kilometer $\left(\mathrm{km}^{2}\right)$ \\
square foot $\left(\mathrm{ft}^{2}\right)$ & 929.0 & square centimeter $\left(\mathrm{cm}^{2}\right)$ \\
square inch $\left(\mathrm{in}^{2}\right)$ & 0.09290 & square meter $\left(\mathrm{m}^{2}\right)$ \\
section $\left(640 \mathrm{acres}^{2}\right.$ or 1 square mile) & 6.452 & square centimeter $\left(\mathrm{cm}^{2}\right)$ \\
square mile $\left(\mathrm{mi}^{2}\right)$ & 259.0 & square hectometer $\left(\mathrm{hm}^{2}\right)$ \\
square mile $\left(\mathrm{mi}^{2}\right)$ & 259.0 & hectare (ha) \\
\hline
\end{tabular}

Vertical coordinate information is referenced to the insert datum name (and abbreviation) here for instance, "North American Vertical Datum of 1988 (NAVD 88).”

Horizontal coordinate information is referenced to the insert datum name (and abbreviation) here for instance, "North American Datum of 1983 (NAD 83)”. 


\title{
Bathymetry and Acoustic Backscatter-Outer Mainland Shelf and Slope, Gulf of Santa Catalina, Southern California
}

\author{
By Peter Dartnell, James E. Conrad, Holly F. Ryan, and David P. Finlayson
}

\begin{abstract}
In 2010 and 2011, scientists from the U.S. Geological Survey (USGS), Coastal and Marine Geology Program, acquired bathymetry and acoustic-backscatter data from the outer shelf and slope region offshore of southern California. The surveys were conducted as part of the USGS Marine Geohazards Program. Assessment of the hazards posed by offshore faults, submarine landslides, and tsunamis are facilitated by accurate and detailed bathymetric data. The surveys were conducted using the USGS R/V Parke Snavely outfitted with a 100-kHz Reson 7111 multibeam-echosounder system. This report provides the bathymetry and backscatter data acquired during these surveys in several formats, a summary of the mapping mission, maps of bathymetry and backscatter, and Federal Geographic Data Committee (FGDC) metadata.
\end{abstract}

\section{Introduction}

The U.S. Geological Survey (USGS), Coastal and Marine Geology Program team members mapped the outer shelf and slope region offshore of southern California from Dana Point to Encinitas in 2010 and 2011. High-resolution bathymetry and co-registered acoustic backscatter data were collected, mainly seaward of the 3-nautical-mile limit of the California State Waters (fig. 1). The mapped area lies between previous high-resolution surveys conducted offshore of Los Angeles and Orange Counties to the north (Gardner and Dartnell, 2002) and offshore of the city of La Jolla to the south conducted by Scripps Institution of Oceanography and Woods Hole Oceanographic Institute (WHOI) (NGDC, 2013). The area shoreward of this survey, mainly within California State Waters, was mapped by California State University, Monterey Bay Seafloor Mapping Lab (CSUMB, 2013), by Fugro Pelagos as part of the California Seafloor Mapping Program (CSUMB, 2013), and by Fugro Pelagos as part of a joint program with the San Diego Association of Governments and the California Department of Fish and Wildlife (SANDAG-CDFW, 2013)

The new USGS data abut the State Waters and extends as far as $18 \mathrm{~km}$ (11 mi) offshore to a maximum water depth of about $800 \mathrm{~m}$ (2,625 ft) (near the depth limit of the multibeam-echosounder system). The area surveyed comprises the outer shelf and slope, and images the slope-basin transition. The area encompasses a diverse physiography, including smooth, relatively featureless slopes, submarine canyons, gullied slopes, uplifted ridges formed by folding of sub-seafloor sediments, sediment wave fields, and scarps associated with active faults. Most of the seafloor surveyed has low backscatter intensities, indicating a seafloor likely composed of finer sediments. A few areas of higher backscatter intensity related to rocky outcrops are present offshore of Dana Point, in parts of the outer shelf, and in a few scattered locations on the slope. 


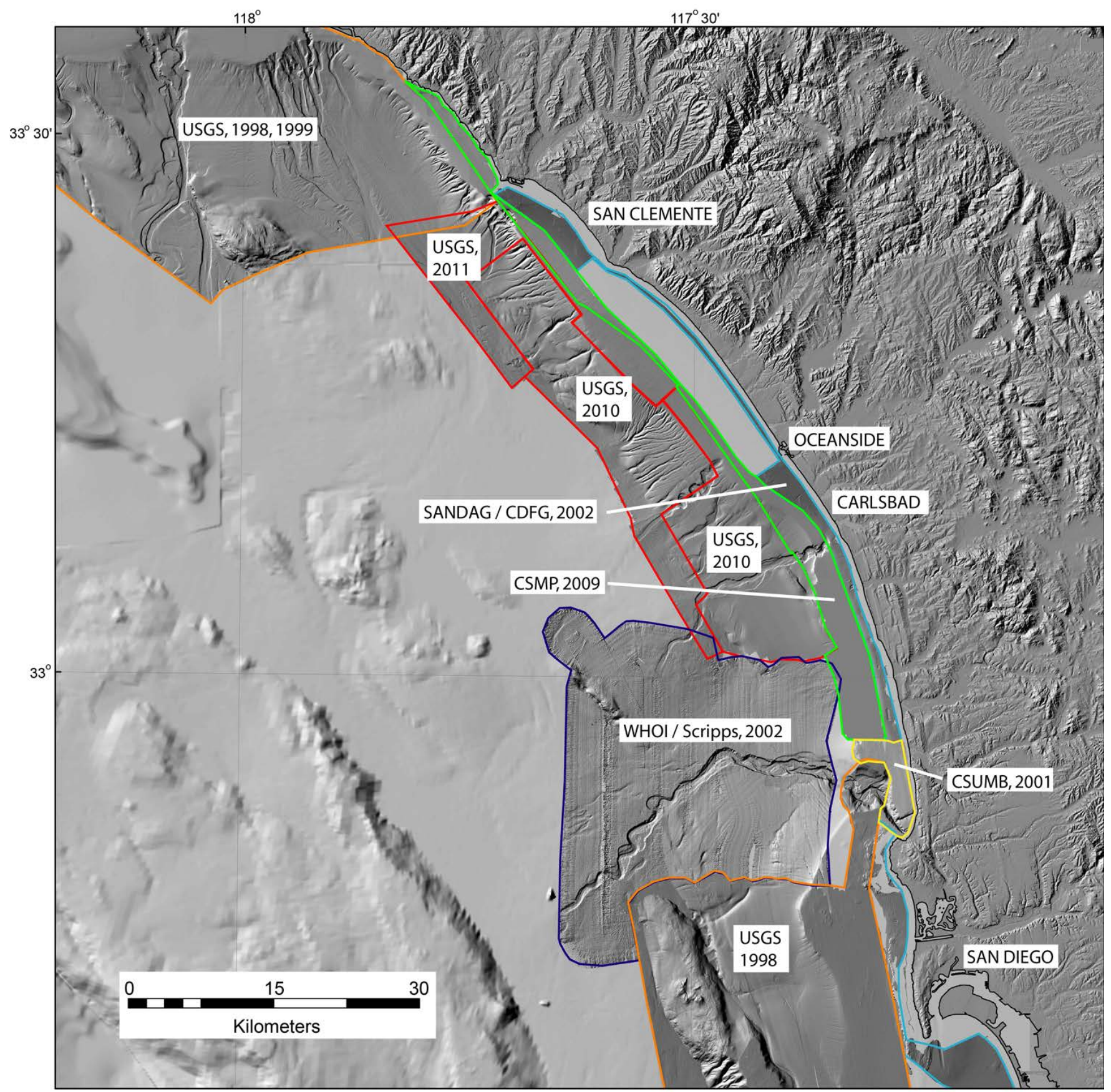

Figure 1. Location map of 2010 and 2011 USGS multibeam echosounder surveys in the Gulf of Santa Catalina, southern California (outlined in red). Previous multibeam echosounder surveys are outlined in orange (USGS), blue (Woodshole Oceanographic Institute and Scripps Institution of Oceanography), cyan (San Diego Association of Governments and CA Dept of Fish and Wildlife), green (partners of the California Seafloor Mapping Program), and yellow (California State University, Monterey Bay). Maps in this report are portrayed in UTM, Zone 11, NAD83 coodinate system. Onshore digital elevation model from USGS, National Elevation Dataset available at $h$ ttp://ned.usgs.gov/. 
These new data can be used to help understand the geology of the outer shelf and slope by showing features related to active faulting and deformation (fig. 2). Detailed bathymetric and acousticbackscatter data provide important information regarding seafloor substrate and marine habitats, sediment transport pathways, and slope stability and potential submarine landslide hazards. This report provides the USGS 2010 and 2011 bathymetry and acoustic-backscatter data in several digital formats along with a summary of the mapping mission, maps of bathymetry and backscatter, and Federal Geographic Data Committee (FGDC) metadata.

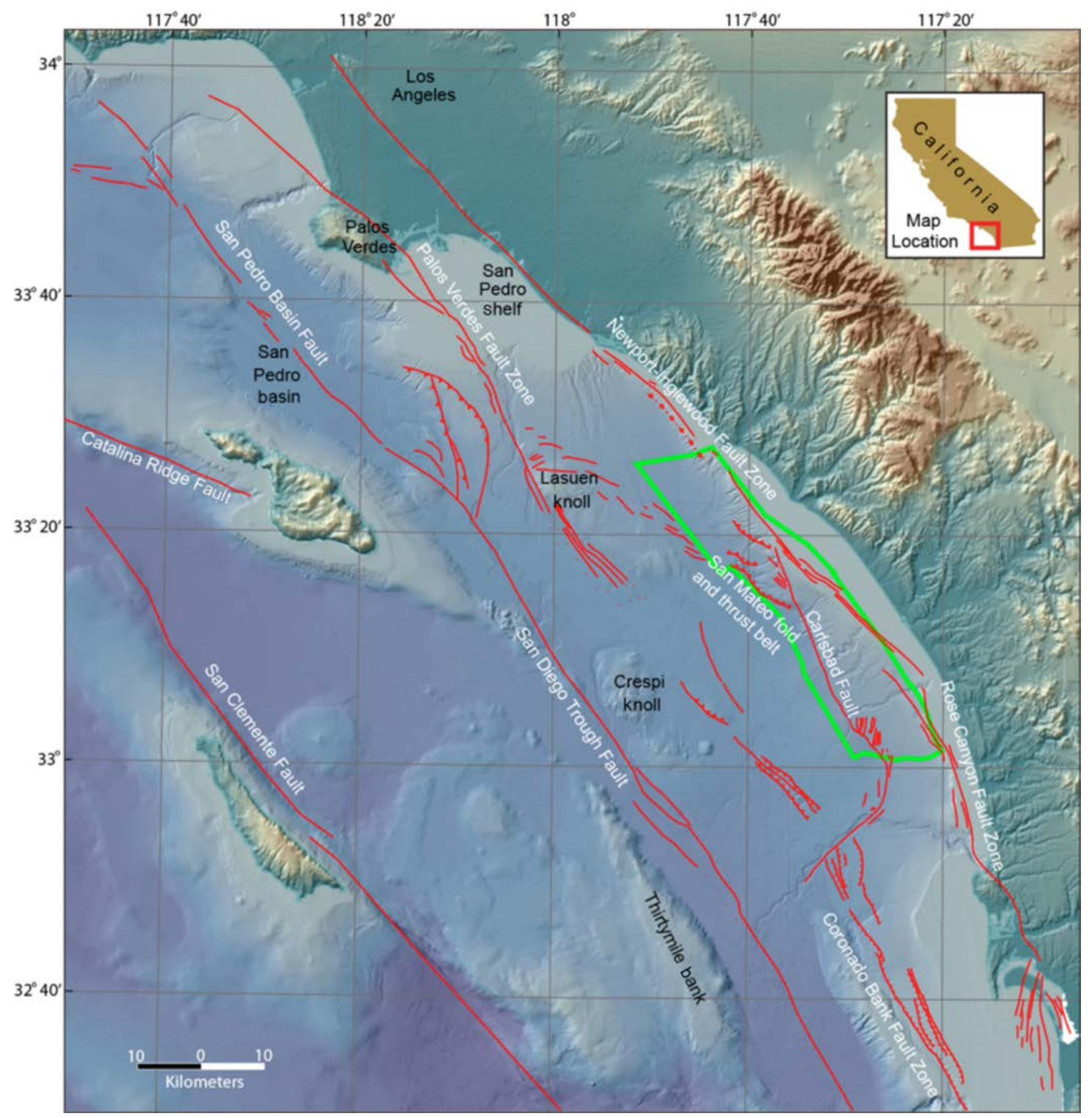

Figure 2. Map of southern California borderland region showing main fault traces (red lines) and outline of 20102011 USGS multibeam surveys (green outline). 


\section{Mapping Mission}

Due to the overall size of the study area, mapping took place during three research cruises (S-1110-SC, S-23-10-SC, and S-07-11-SC) spanning a two-year period between 2010 and 2011 (USGS CMG, 2013). The three surveys were conducted using a 100-kHz Reson 7111 multibeam echosounder. The 7111 is a horseshoe shaped sonar that was mounted on the 34-foot USGS mapping vessel $R / V$ Parke Snavely (fig. 3) and affixed to a hull brace. The multibeam system receives acoustic returns from 101, 201 , or 301 beams depending on the setting. Individual beams are $1.9^{\circ}$ along-track and $1.5^{\circ}$ across-track providing a combined $150^{\circ}$ swath at maximum. Table 1 provides the sonar system specifications. Differentially Corrected Global Positioning System (DGPS) navigational data were passed through a CodaOctopus F190 inertial measurement unit (IMU) to the sonar hardware and data collection software. The $R / V$ Parke Snavely was outfitted with three networked workstations and a navigation computer for use by the captain and survey crew for data collection and initial processing.

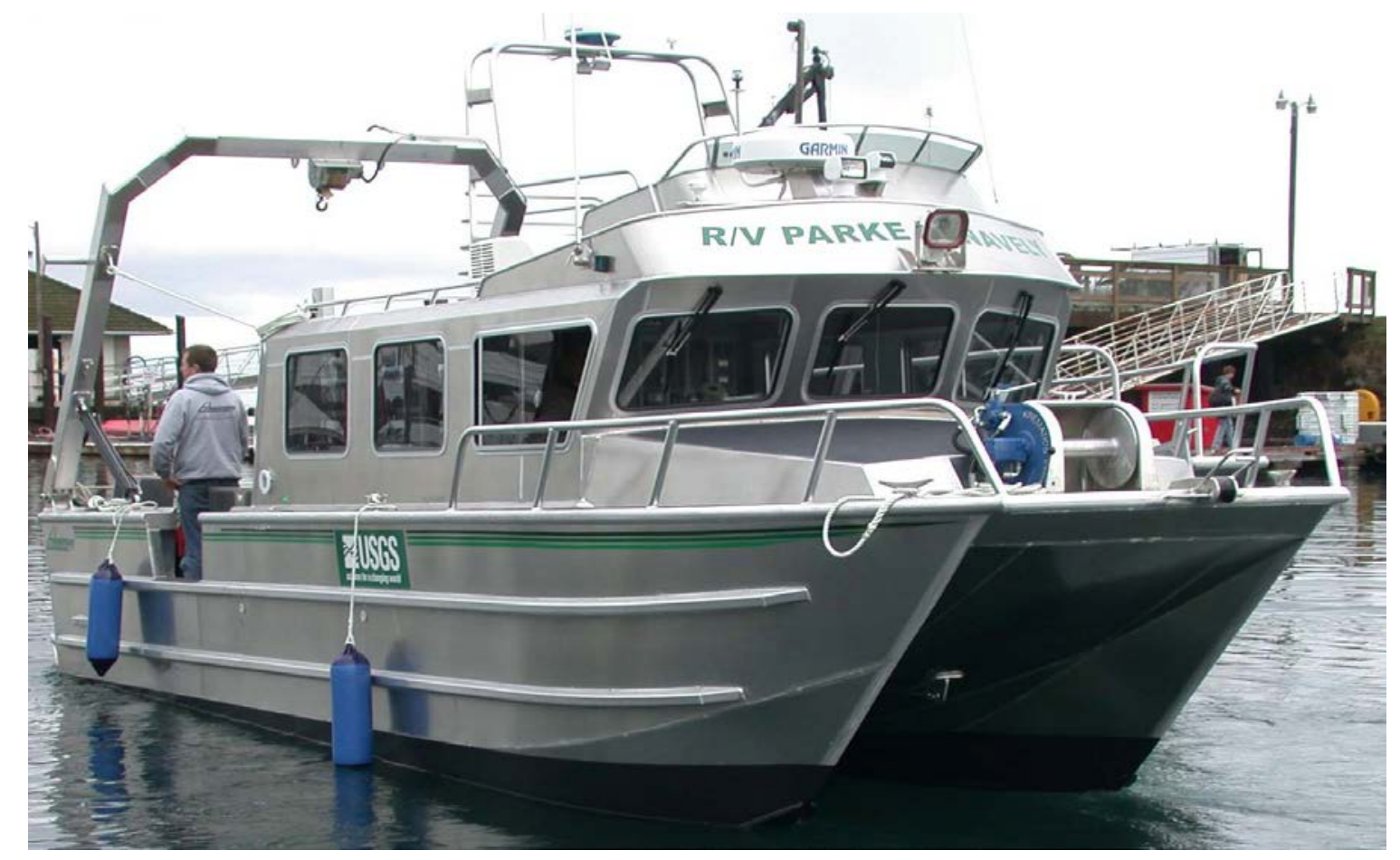

Figure 3. Photograph of U.S. Geological Survey Research Vessel Parke Snavely.

The first survey in 2010 (S-11-10-SC) was completed in 8 days from May 10 to May 17, while the second survey (S-23-10-SC) was completed in 7 days from November 11 to November 17. The 2011 survey was completed in 10 days from June 3 to June 12. The three mapping missions collected bathymetry and acoustic-backscatter data over a combined total of $670 \mathrm{~km}^{2}$ (258 $\mathrm{mi}^{2}$ ) of seafloor in water depths ranging from 44 to $792 \mathrm{~m}$ (144 to 2,598 ft). 
Table 1. Reson 7111 multibeam echosounder sonar specifications (http://www.reson.com/products/seabat/seabat7111).

\begin{tabular}{ll}
\hline Sonar & Reson-7111 \\
Frequency & $100 \mathrm{kHz}$ \\
Beams & 101,201 equal angle or 301 equal distance \\
Swath & 150 degrees coverage (7.5x depth) \\
Minimum Depth & 3 meters \\
Maximum Depth & 1,000 meters \\
Typical Depth & 900 meters \\
Pulse Length & 0.08 ms to $3.04 \mathrm{~ms}$ \\
\hline
\end{tabular}

Tides

Nearshore multibeam surveys can take advantage of geodetic control from shore-based Global Positioning System (GPS) base stations broadcasting real-time kinematic (RTK) corrections via UHF frequencies. These three surveys however, were conducted farther offshore outside the range of UHF radio coverage. Therefore, depth values during the surveys were based on tidal datums and then postprocessed to ellipsoid elevations. During all three surveys (S-11-10-SC, S-23-10-SC, and S-07-11-SC), tidal corrections from the La Jolla tide station (9410230) were used. Tide values exported from the tide station were referenced to the North American Vertical Datum of 1988 (NAVD 88). There is a 0.058-m vertical difference between the NAVD 88 datum $(1.389 \mathrm{~m})$ and the Mean Lower Low Water (MLLW) datum $(1.331 \mathrm{~m})$ at this station (http://tidesandcurrents.noaa.gov/geo.shtml?location=9410230).

\section{Data Processing}

\section{Vessel Position and Attitude}

The $R / V$ Parke Snavely was equipped with a CodaOctopus F190 inertial motion unit (IMU) for the duration of the three surveys. The F190 received DGPS-aided positional navigation from dual Trimble model 4000 DGPS receivers, and commercial C-Nav satellite differential stations. The DGPS data were combined with the inertial vessel motion measurements (pitch, roll, heading, and heave) directly within the F190 hardware so that high-precision position and attitude corrections were fed in real time to the sonar acquisition equipment.

\section{Sound Velocity Measurements}

Sound velocity measurements were collected continuously with an Applied Micro Systems Micro sound velocimeter (SV) deployed on the transducer frame for real-time sound velocity adjustments at the transducer-water interface. The Micro SV is accurate to $\pm 0.03 \mathrm{~m} / \mathrm{s}$. In addition, sound velocity profiles (SVP) were collected approximately every 2 hours throughout each survey day with an Applied Micro Systems, SvPlus 3472. This instrument provided time-of-flight sound-velocity 
measurements by using invar rods with a sound-velocity accuracy of $\pm 0.06 \mathrm{~m} / \mathrm{s}$. Pressure was measured by a semiconductor bridge strain gauge to an accuracy of 0.15 percent ( $500 \mathrm{dbar}$, full scale) and temperature was measured by thermistor with an accuracy of 0.05 degrees Celsius (Applied Microsystems Ltd., 2005).

\section{Sonar Sounding Processing}

DGPS data and measurements of vessel motion were combined in the F190 hardware to produce a high-precision vessel attitude packet. This packet was transmitted to the PDS2000 acquisition software in real time and combined with instantaneous sound velocity measurements at the transducer head before each ping. The returned samples were projected to the seafloor using a ray-tracing algorithm working with the previously measured sound-velocity profiles in the PDS2000 software. Finally, the processed data were stored line-by-line as Reson S7K files.

\section{Digital Terrain Model Production}

CARIS HIPS and SIPS (version 7.1.1 Service Pack 3) bathymetry processing software was used to further clean and bin the raw bathymetry. Processed S7K files were imported to CARIS and field sheets were created within CARIS to encompass the entire survey area.

Survey lines were filtered to remove obvious erroneous soundings and soundings towards the noisier outer beams and then added into the appropriate field sheet. CARIS base surfaces were created for each field sheet at 5- and 20-m resolutions using the CUBE surface type. The 20-m base surfaces included the entire survey area, while the 5-m base surfaces included only the shallower shelf and upper slope regions (water depth less than $200 \mathrm{~m}$ ). The finalized base surfaces were then exported as ASCII XYZ files (x-coordinate, y-coordinate, depth) in UTM, Zone 11, World Geodetic System of 1984 (WGS84, G1150) coordinates relative to the North American Vertical Datum of 1988 (NAVD 88). These data were gridded in Fledermaus (QPC) software (Version 7.1) at 5- and 20-m resolutions and the resulting surfaces were converted to ASCII Raster format files and imported into a Geographic Information System (ESRI, ArcMap). Grids were projected horizontally to the North American Datum of 1983 (CORS96) using the ESRI “WGS_1984_(ITRF00)_To_NAD_1983 (CORS96)” function in ArcTools. Finally, the individual 20-m resolution bathymetry surfaces were merged into one continuous surface (fig. 4), and similarly the individual 5-m resolution surfaces were merged into one continuous surface. This 5-m surface was also merged with the in-shore bathymetry data collected by CSUMB, SANDAG, CDFW, and Fugro Pelagos. All of these bathymetric surfaces are available in the online “Data Catalog” section of this report (http://pubs.usgs.gov/of/2014/1094/datacatalog/). 


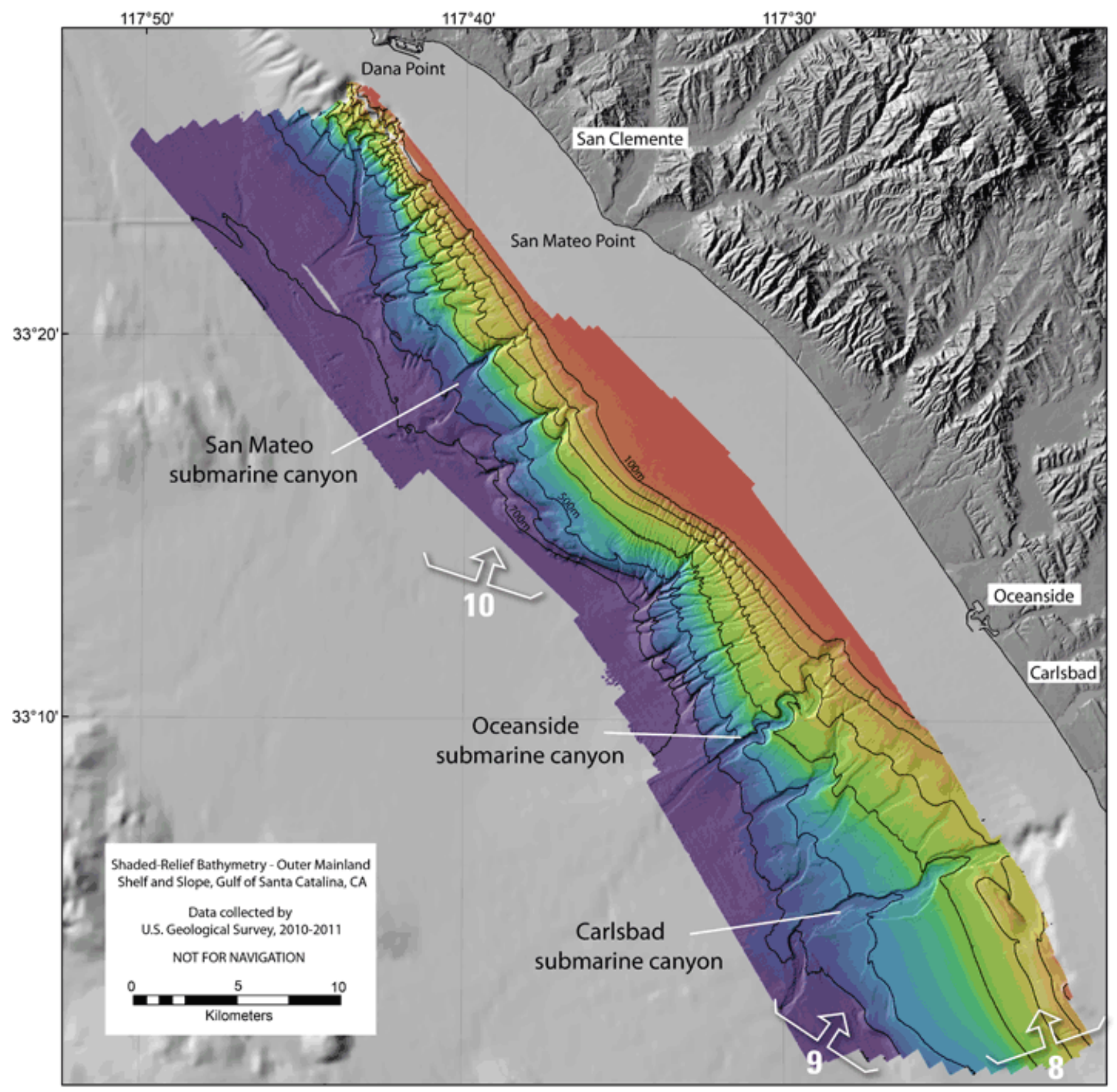

Figure 4. Plan view of shaded-relief bathymetry, offshore southern California. 2010 and 2011 USGS mapped area is colored for depth; reds (shallower) to purples (deeper). Range of depths is 44 to $792 \mathrm{~m}$. Numbered arrows show viewing directions of perspective views in figures 8-10. 


\section{Bathymetric Uncertainty Estimation}

One measure of the reliability of bathymetric data is to measure the standard deviation of all the soundings that contributed to each bathymetric grid cell. Standard deviation shows how much variation exists around the mean value. Low standard deviation indicates that all of the soundings are close to the mean whereas, high standard deviation indicates the soundings are spread over a large range of values. Sounding variability can come from a number of factors including, natural seafloor terrain, water depth, and data collection artifacts. Rock outcrops will have naturally higher standard deviation values than a homogeneous muddy seafloor because rock is typically not smooth. Also, a region with more data collection artifacts, such as towards the outer beams of each multibeam swath, will have a higher standard deviation than near the middle of the swath. Standard deviation grids were exported as XYZ files from each survey's Caris 20-m Cube BASE surface and imported into an ArcGIS GRID. Figure 5 shows a sub-area of the standard deviation grids for surveys S-11-10-SC and S-23-10-SC. The grids represent one sigma, or 68\% confidence interval, with dark blues representing low standard deviation and reds representing high standard deviation. This grid shows higher standard deviation values resulting from natural seafloor terrain, such as the steeper slopes of the canyon and gully walls as well as artificial linear regions of higher standard deviation from overlapping swaths. Standard deviation statistics for each survey are shown in table 2. Entire survey standard deviation grids for each survey are available in ASCII Raster format files in the "Data Catalog” section of this report.

To measure how standard deviation varies with depth, 1 percent of the original Caris Cube BASE surface standard deviation XYZ values were randomly subsampled. These values were plotted versus depth (fig. 6), and not surprisingly, show an increase in standard deviation with depth. 


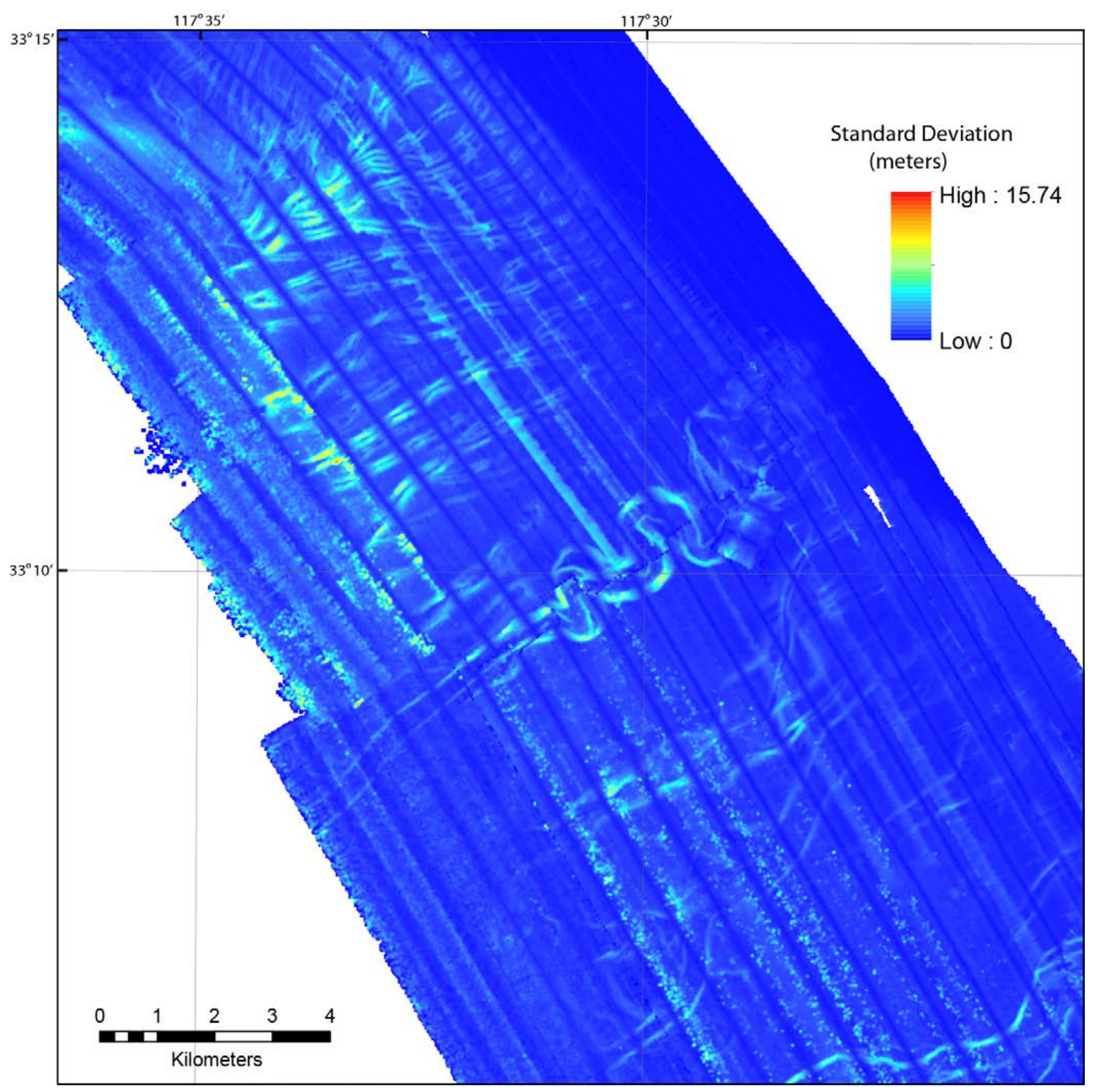

Figure 5. Map showing sub-area of bathymetric standard deviation grid for USGS surveys S-11-10-SC and S-2310-SC. 


\section{S-07-11-SC}

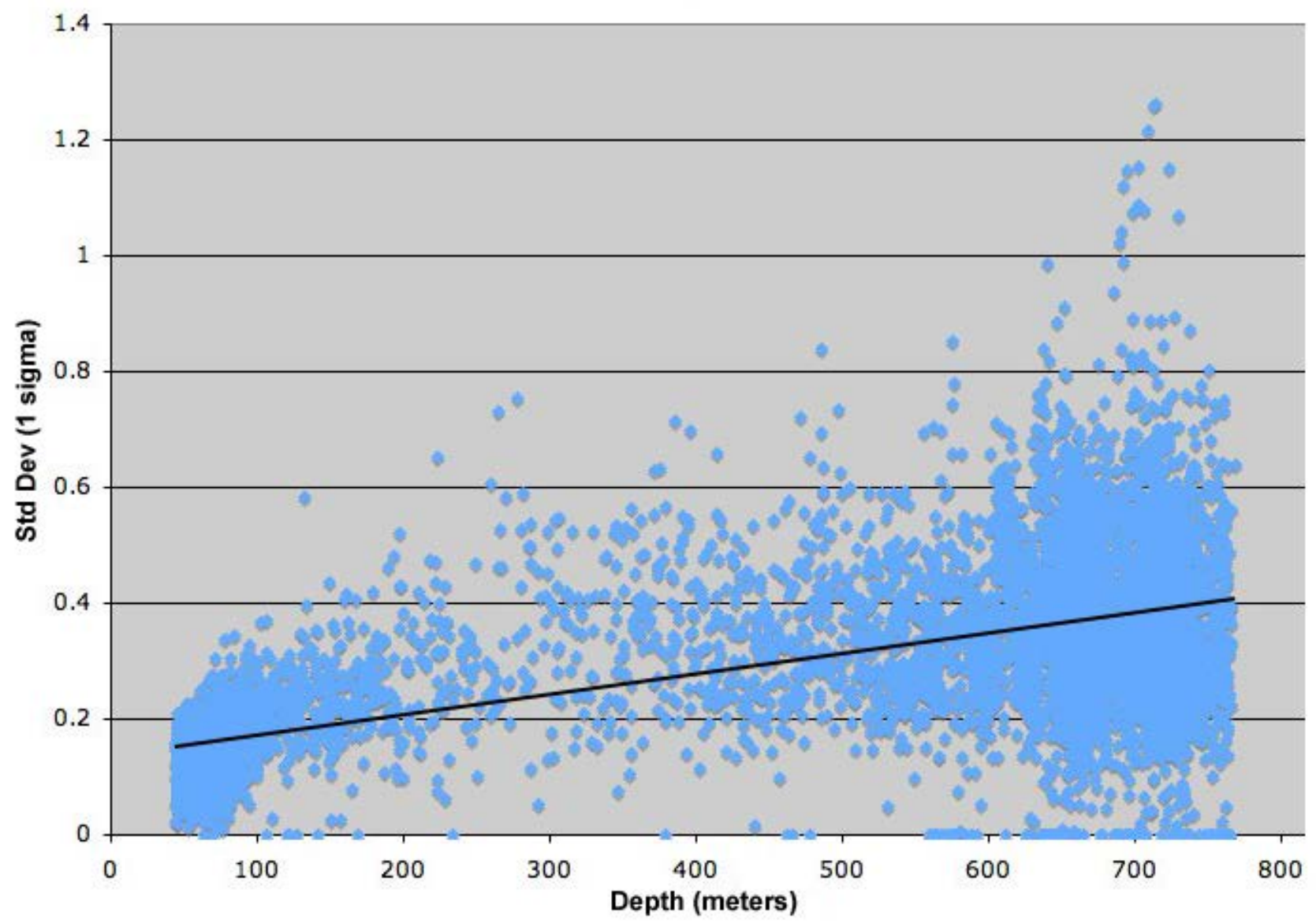

Figure 6. Plot of randomly selected standard deviation values versus water depth for USGS survey S-07-11-SC. Black line shows general trend of all points and shows that standard deviation increases with depth.

Table 2. Standard deviation statistics for three USGS surveys that comprised the Gulf of Santa Catalina mapping.

\begin{tabular}{|l|c|c|c|}
\hline & $\begin{array}{c}\text { USGS Survey } \\
\text { S-11-10-SC }\end{array}$ & $\begin{array}{c}\text { USGS Survey } \\
\text { S-23-10-SC }\end{array}$ & $\begin{array}{c}\text { USGS Survey } \\
\text { S-07-11-SC }\end{array}$ \\
\hline Minimum Std Dev $(\mathrm{m})$ & 0 & 0 & 0 \\
\hline Maximum Std Dev $(\mathrm{m})$ & 15.01 & 15.74 & 29.78 \\
\hline Mean Std Dev $(\mathrm{m})$ & 0.88 & 1.37 & 1.10 \\
\hline
\end{tabular}

\section{Backscatter Image Production}

The multibeam-echosounder backscatter data were processed using the Fledermaus (version 7.3.2) integration of Geocoder. Caris HDCS line files were exported as GSF line files and imported into Fledermaus along with the corresponding original Reson S7K files. Adjustments were made to the line files including TX/RX (transmit/receive) power gain, beam pattern, and adaptive angle-varying gain corrections. The line files were then mosaicked into $10-\mathrm{m}$ resolution images. The images were then exported as georeferenced TIFF images, imported into a GIS, and converted to GRIDs at 10-m resolution. The grids were projected horizontally from UTM, Zone 11, WGS-84 coordinates to UTM, Zone 11, NAD-83 (CORS96) coordinates using the ESRI "WGS_1984_(ITRF00)_To_NAD_1983 (CORS96)" function in ArcTools. Finally the GRIDs were exported as geoTIFF images (fig. 7). 
In the backscatter imagery, brighter tones indicate higher backscatter intensity, and darker tones indicate lower backscatter intensity. The intensity represents a complex interaction between the acoustic pulse and the seafloor, as well as characteristics within the shallow subsurface, providing a general indication of seafloor texture and composition. Backscatter intensity depends on acoustic source level; frequency used to image the seafloor; beam grazing angle; composition and character of the seafloor, including grain size, water content, bulk density, and seafloor roughness; and amount and type of biological cover. Harder and rougher bottom types, such as rocky outcrops or coarse sediment, typically return stronger intensities (high backscatter, lighter tones), whereas softer bottom types, such as fine sediment, return weaker intensities (low backscatter, darker tones).

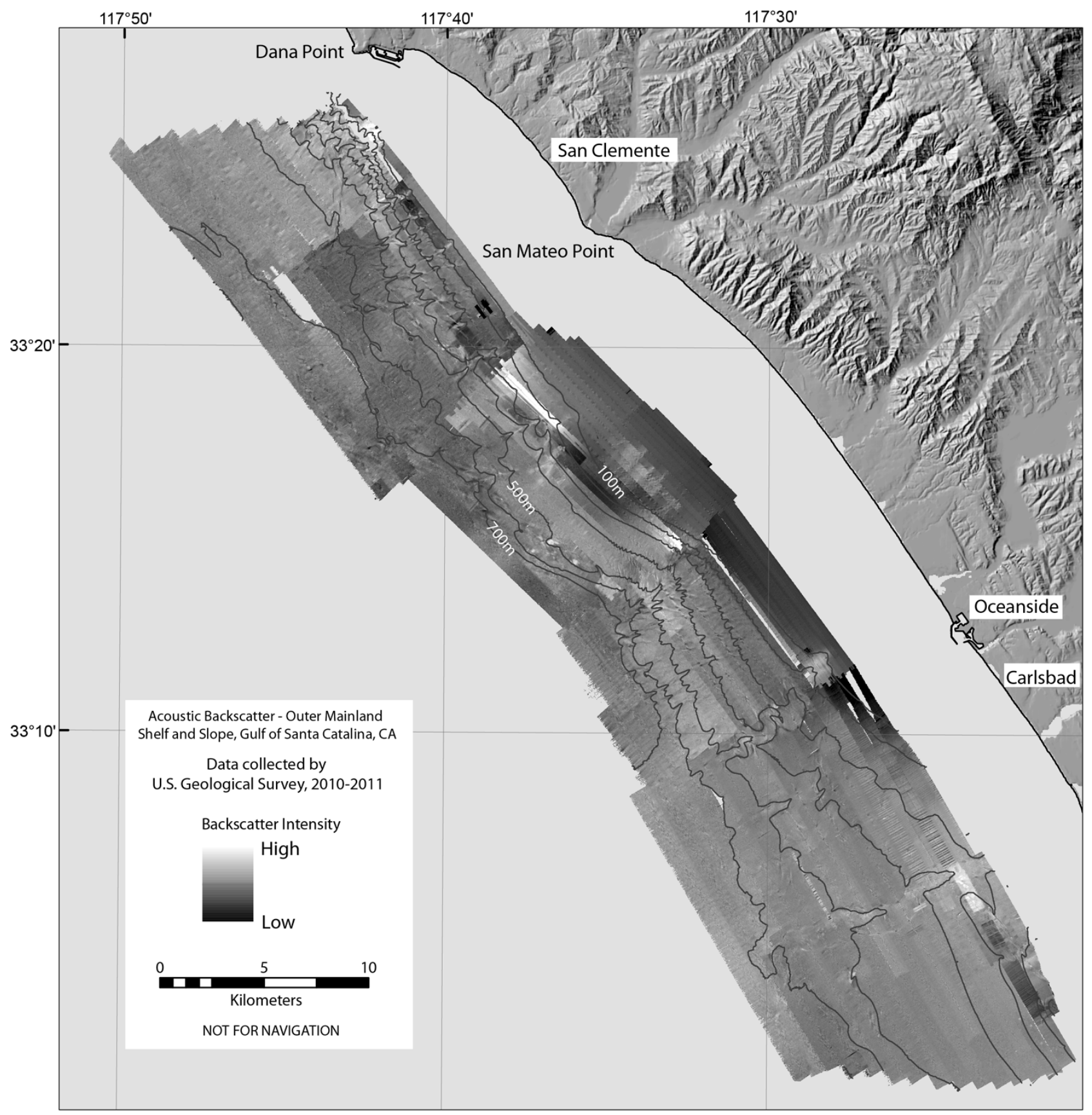

Figure 7. Map showing acoustic-backscatter imagery of offshore southern California from 2010 and 2011 USGS multibeam-echosounder surveys. 


\section{Survey Results}

The 2010 and 2011 USGS surveys of the outer mainland shelf and slope of the Gulf of Santa Catalina in southern California covered over $670 \mathrm{~km}^{2}\left(258 \mathrm{mi}^{2}\right)$. Observed depths ranged from $44 \mathrm{~m}$ to $792 \mathrm{~m}$ (fig. 4). The survey area follows the outer shelf and slope for about $58 \mathrm{~km} \mathrm{(36} \mathrm{mi).} \mathrm{Backscatter}$ intensities suggest that the majority of the seafloor mapped is covered by soft sediment, with bedrock exposed in the far north off Dana Point, on the shelf offshore Camp Pendleton, and in a few scattered locations on the slope (fig. 7).

In most places, the slope is cut by a variety of channels and gullies. Main channel systems include the San Mateo, Oceanside, and Carlsbad submarine canyons (fig. 4), which serve as the primary conduits carrying sediment off the shelf and into offshore basins. These canyons are largely inactive during sea level high stands, but become active during low stands when the shoreline is at the shelf edge (Covault and others, 2007). Several partly buried and apparently older abandoned channels lie between Oceanside and Carlsbad canyons. Other parts of the slope are cut by numerous narrow gullies extending down slope, including the area offshore of San Clemente, and a zone extending for about $10 \mathrm{~km}(6 \mathrm{mi})$ along the slope offshore of Camp Pendleton, northwest of Oceanside. In contrast, south of Carlsbad canyon, the slope is relatively smooth with little to no gully development. In general, within the survey area, the slope becomes wider to the south. The slope is about $5 \mathrm{~km}$ (3 mi) wide in the north and is characterized by relatively short, deep, and narrow gullies. The slope generally widens southwards, becoming about $12 \mathrm{~km}$ (8 mi) wide offshore Oceanside and Carlsbad. This area is characterized by channelized submarine canyon systems rather than gullies.

The survey area is cut by several important fault systems, which influence outer shelf and slope bathymetry. The Newport-Inglewood and Rose Canyon Fault Zones (Ryan and others, 2009) extend along the outer shelf along the northeastern edge of the study area, generally coincident with the shelf break. In the southeastern corner of the study area, uplifted ridges adjacent to strands of the Rose Canyon Fault Zone are on the upper slope and shelf edge (fig. 8).

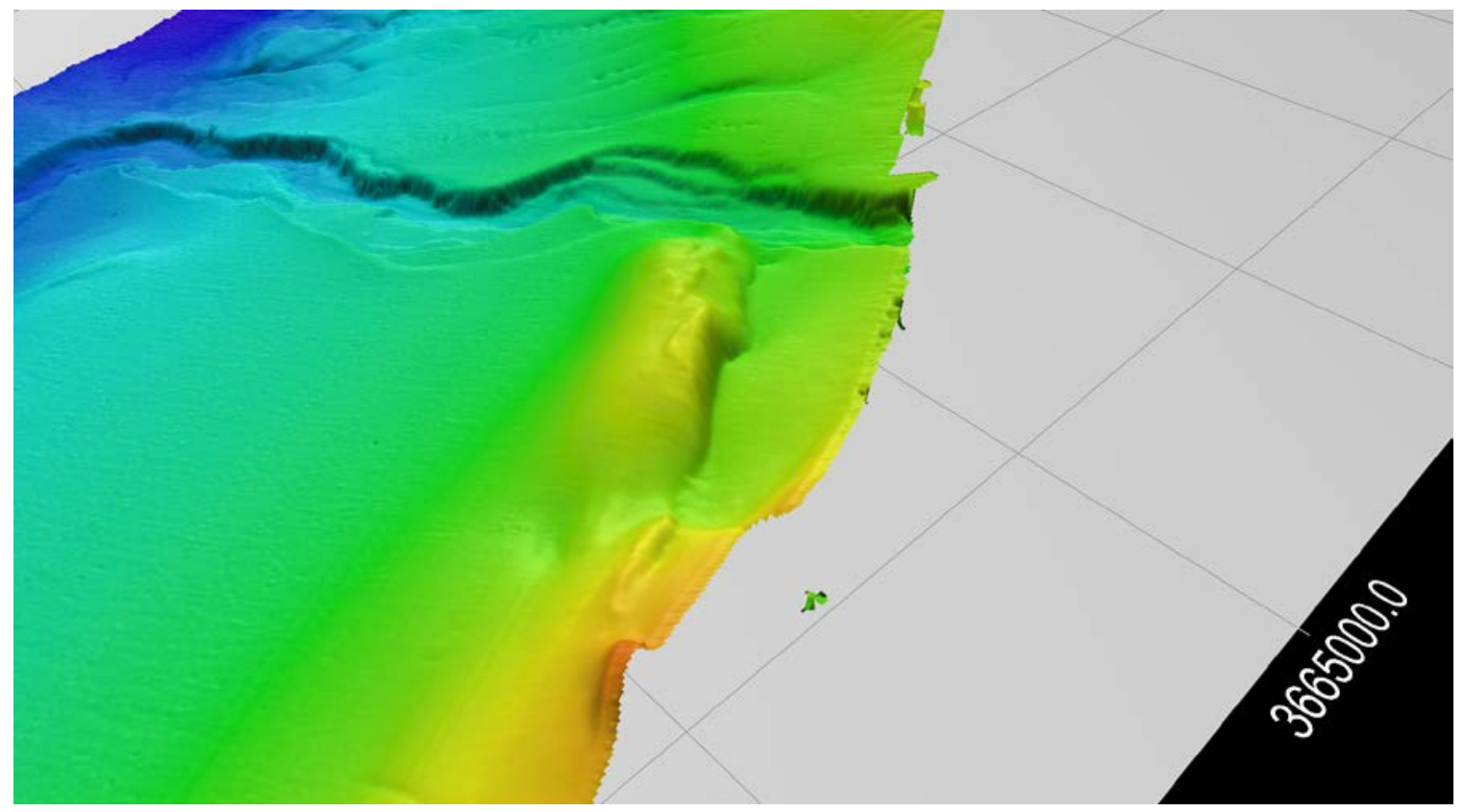

Figure 8. Perspective view of colored shaded-relief bathymetry, looking northwest, showing an uplifted ridge on upper slope adjacent to Rose Canyon Fault Zone. Carlsbad submarine canyon extends across slope just north of the ridge. Area is colored to show depth: orange (shallower) to blue (deeper). Vertical exaggeration of perspective view, $5 x$; distance across bottom, $\sim 4 \mathrm{~km}$. See figure 4 for viewing direction. 
To the north, offshore Camp Pendleton, folded strata along the Newport-Inglewood Fault Zone forms irregular bedrock ridges with relief of 1-2 m (3-6 ft) visible in bathymetric and backscatter data. In the southern part of the study area offshore Encinitas, scarps of several northeast-trending normal faults are present near the base of the slope fig. 9). Offshore San Mateo Point and the northern part of Camp Pendleton, numerous north-northwest-trending folds associated with the San Mateo fold and thrust belt (Ryan and others, 2009) extend from the mid to lower slope (fig. 10). These folds are expressed as a series of bulge-like ridges that trend obliquely across the slope in this area, in contrast to more constant slope gradients to the north and south. North of these folds, sediment waves associated with the San Mateo submarine channel system are present on the lower slope.

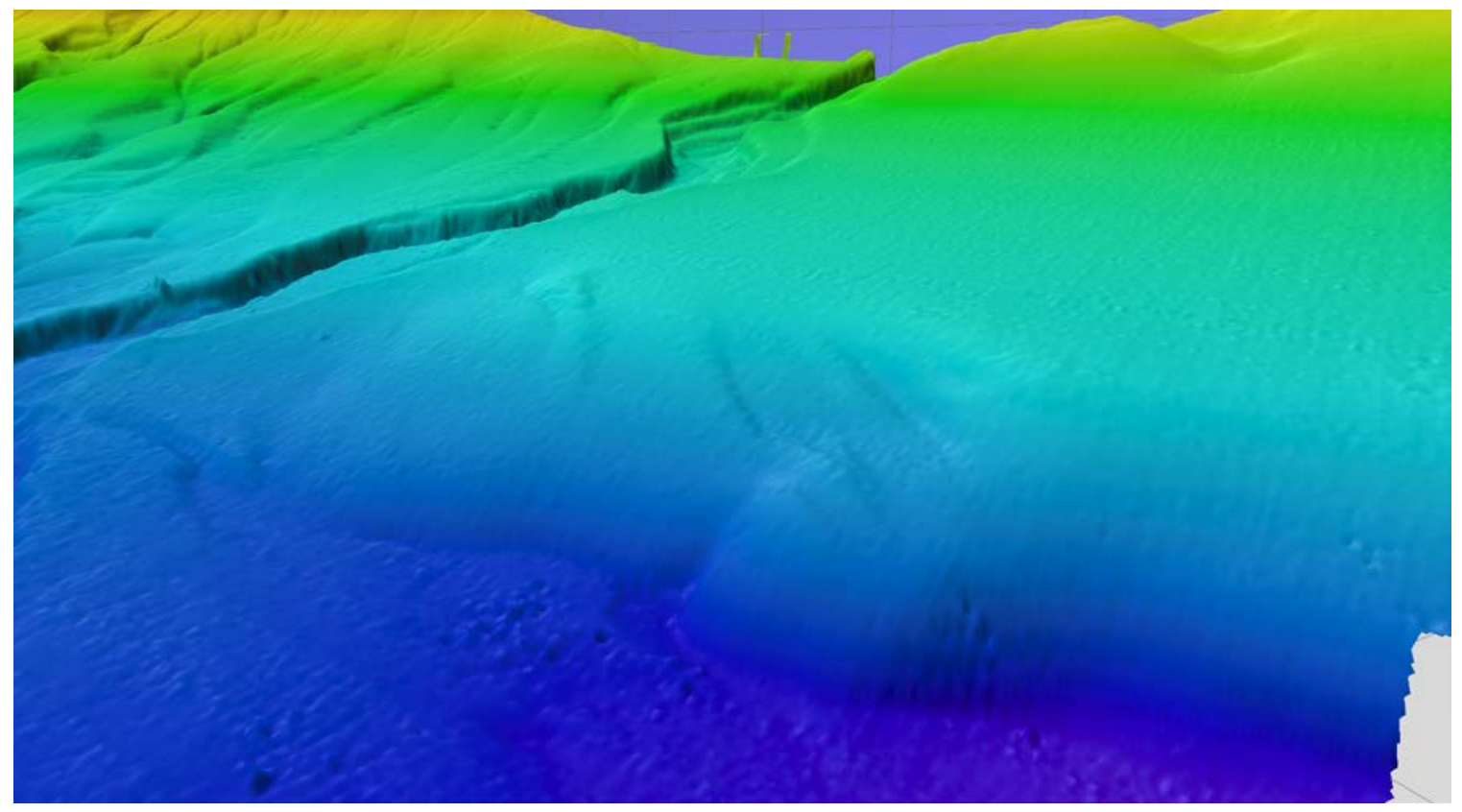

Figure 9. Perspective view of colored shaded-relief bathymetry, looking northeast, showing a set of northeasttrending fault scarps near base of slope. Carlsbad submarine canyon cuts slope in middle distance, and older, abandoned canyons are shown in upper left area of image. Area is colored to show depth: yellow (shallower) to blue (deeper). Vertical exaggeration of perspective view, $5 x$; distance across bottom, $\sim 5 \mathrm{~km}$. See figure 4 for viewing direction. 


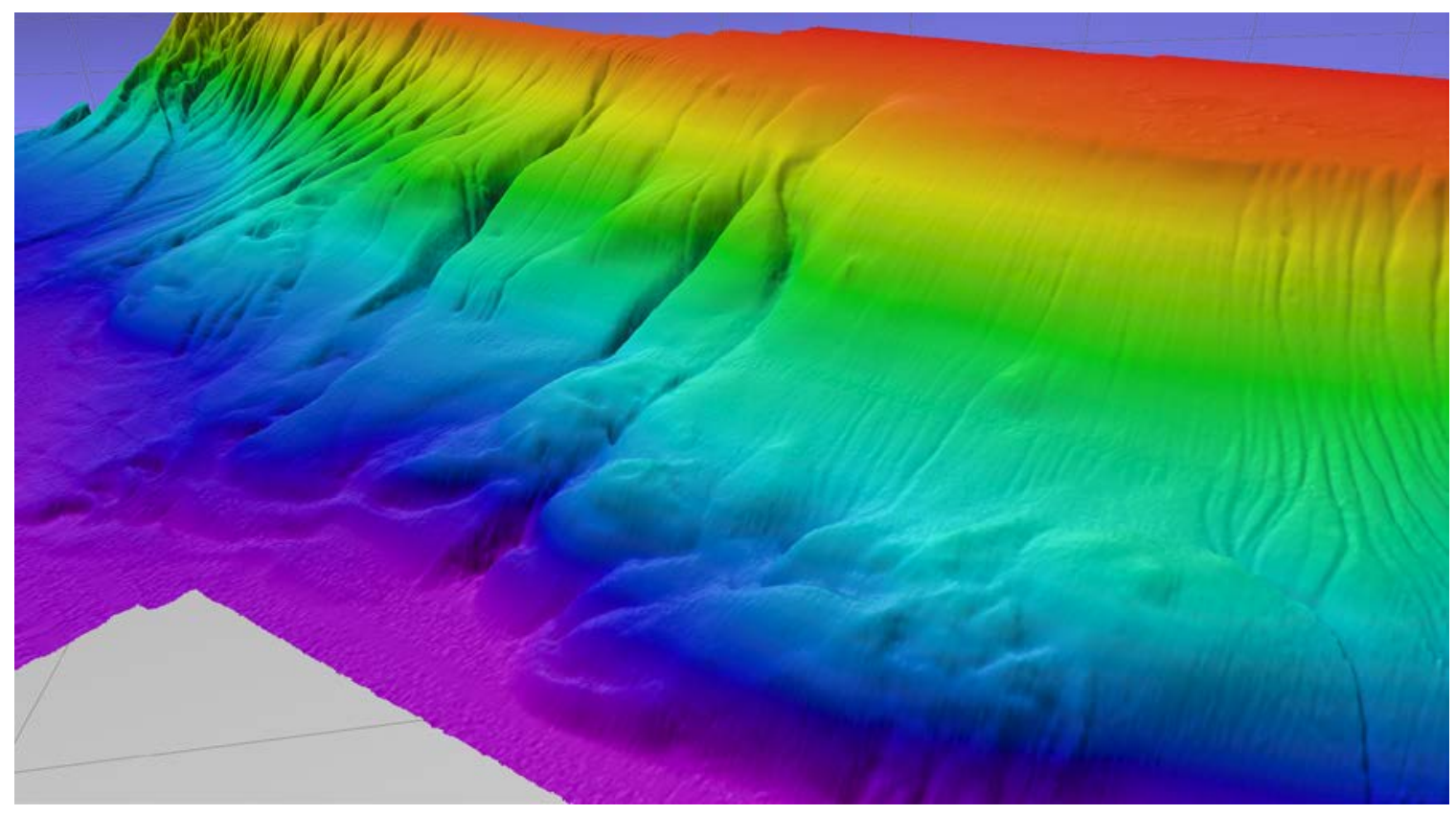

Figure 10. Perspective view of colored shaded-relief bathymetry, looking northeast, showing lumpy, bulge-like morphology of lower and mid-slope caused by folds and faulting of the San Mateo fold and thrust belt. Area is colored to show depth: red (shallower) to purple (deeper). Vertical exaggeration of perspective view, $5 x$; distance across bottom, $\sim 7 \mathrm{~km}$. See figure 4 for viewing direction.

NOTE THAT THE USGS COLLECTS BATHYMETRIC DATA FOR SCIENTIFIC PURPOSES ONLY. THE USGS DOES NOT GAURANTEE THAT FULL BOTTOM SEARCH HAS BEEN ACHIEVED AND THE DATA HAVE NOT BEEN INSPECTED FOR DANGERS TO NAVIGATION.

\section{Acknowledgements}

This work was funded by the Marine Geohazards Program of the U.S. Geological Survey. Thanks to Florence Wong and Steve Hartwell for reviewing this report. Also thanks to Jamie Grover, Pete Dal Ferro, and Greg Gable as captains of the R/V Parke Snavely, to ET's Rob Wyland, Jackson Currie, and Gerry Hatcher for support with data acquisition.

\section{References Cited}

Applied Microsystems Ltd., 2005, SVplus sound velocity, temperature, and depth profiler user's manual, revision 1.23: Sidney, B.C., Canada. 39 p.

California State University, Monterey Bay (CSUMB) [2013], Seafloor Mapping Lab (SFML) data library Web page, at http://seafloor.otterlabs.org/SFMLwebDATA.htm.

Covault, J.A., Normark, W.W., Romans, B.W., and Graham, S.A., 2007, Highstand fans in the California Borderland: The overlooked deep-water depositional systems: Geology, v. 35, no. 9, p. 783-786.

Gardner, J.V., and Dartnell, P., 2002, Multibeam mapping of the Los Angeles, California margin: U.S. Geological Survey Open-File Report 2002-162, at http://pubs.usgs.gov/of/2002/0162/.

National Geophysical Data Center (NGDC) [2013], Bathymetry and Global Relief Web page, at http://www.ngdc.noaa.gov/mgg/bathymetry/. 
Ryan, H.F., Legg, M.R., Conrad, J.E., and Sliter, R.W., 2009, Recent faulting in the Gulf of Santa Catalina: San Diego to Dana Point, in Earth Science in the Urban Ocean: The Southern California Continental Borderland, Lee, H.J., and Normark, W.R., eds., Geological Society of America Special Paper 454, Boulder, Colorado, p. 291-315.

San Diego Association of Governments, and the California Department of Fish and Wildlife (SANDAGCDFW) [2013], bathymetry data available for download at ftp://ftp.dfg.ca.gov/R7_MR/BATHYMETRY/BAT_SCSR_SANDAG.zip.

U.S. Geological Survey Coastal and Marine Geology (USGS CMG) Infobank [2013], S-11-10-SC Metadata Web page at, http://walrus.wr.usgs.gov/infobank/s/s1110sc/html/s-11-10-sc.meta.html.

U.S. Geological Survey Coastal and Marine Geology (USGS CMG) Infobank [2013], S-23-10-SC Metadata Web page at, http://walrus.wr.usgs.gov/infobank/s/s2310sc/html/s-23-10-sc.meta.html. U.S. Geological Survey Coastal and Marine Geology (USGS CMG) Infobank [2013], S-07-11-SC, Metadata Web page at, http://walrus.wr.usgs.gov/infobank/s/s0711sc/html/s-07-11-sc.meta.html. 